\title{
Position of employees in the state-owned enterprises in achieving a welfare state
}

\author{
Christian Orchard Perangin angin* and Bismar Nasution \\ Doctoral Program in Law, Faculty of Law, Universitas Sumatera Utara, Medan, Indonesia
}

\begin{abstract}
Indonesia is a welfare state where the people are guaranteed to get a decent standard of living. The establishment of State-Owned Enterprises (SOEs) is part of the responsibility of the State in the prosperity of its people. The SOEs management cannot be separated from the aspect of labor. Law No. 13 of 2013 on Manpower (UUK) opens an opportunity for entrepreneurs, including state-owned enterprises, to practice the outsourcing recruitment. This research is conducted based on normative and supported by bibliographic data. The theories of Justice and Welfare State were used to analyze the problems. Outsourcing not providing certainty of employment as well as violating the workers' normative rights. In conclusion, the practice of the outsourcing recruitment at SOEs that violates the workers' normative rights will have a profound effect. The absence of certainty guarantee during work will only turn workers as an object of commodity. This activity will hinder people from achieving the justice and prosperous state which has become the goal of the state. The fulfillment of SOEs workers' rights in achieving the welfare state will only be attained if the company can treat workers as partners.
\end{abstract}

\section{Introduction}

The fourth Paragraph of The Preamble to the 1945 Constitution of the Unitary State of the Republic of Indonesia (UUD 1945) declares that the purpose of Indonesia as a state is to promote the common welfare and educate the life of the nation based on the principle of social justice for all Indonesian people. The formulation is then manifested into the Constitution serving as guidelines for the national life and state administration.

Article 27 Paragraph 2 of the 1945 Constitution states that every citizen deserves the right to work and get a decent standard of living for humanity. Then Article 28A stipulates that everyone has the right to live and maintain his life and living. Furthermore, other rights are also regulated in Articles 28B, 28C, 28H, 31, 33 and 34. Article 34 Paragraph 1 asserts that the poor and neglected children are kept by the state. After the fourth amendment, Article 34 Paragraph 2 clarifies that the state task in the field of social welfare is expanded with additional responsibility for developing social security system and empowering the poor, as well as providing health services and public service facilities for the people.

The above descriptionshave clearly defined Indonesia as a welfare state where the people are guaranteed to get a decent standard of living. Welfare state is defined as the

${ }^{*}$ Corresponding author: orchard27christian@gmail.com 
concept of government in which the state plays a key role in safeguarding and promoting the economic and social welfare of its citizens.[1]

The word welfare contains at least three subclassifications: (1) Social welfare, which refers to the collective acceptance of welfare; (2) Economic welfare, which refers to the security guarantee through formal markets or economies; and (3) State welfare, which refers to the guarantee of social welfare services through agents of the state. The welfare state is briefly defined as a country in which state governments are held accountable for ensuring minimum welfare standards for every citizen.[2]

In a welfare state, the power (in terms of economic and political policies) is aimed at: 1) ensuring that every citizen and his family earn the minimum income according to the standards of eligibility, 2) providing social services for every problem that citizens experience (due to illness, old age, or unemployment), as well as other conditions such as economic crisis, 3) ensuring that every citizen gets his rights regardless of differences in status, economy class, and other differences.[3]

The establishment of State Owned Enterprises (SOEs) is part of the state's responsibility for the prosperity of its people. Article 33 Paragraph 2 of the 1945 Constitution mandates that the production sectors that are important for the State and affect the livelihood of the public are controlled by the State. SOEs are public companies that contribute to the development of the state economy/income, pioneer business activities and support government policies in the field of economy and development.[4] In addition, SOEs also serve as a tool to foster profits. To do such mission, SOEs adopt several forms such as Persero, Perjan and Perum. Thus, the functions and roles of these SOEs are essential to maintaining the economic stability of the country and can affect government policies including the state political affairs.[5]

In the beginning, SOEs were the nationalized former foreign companies (Dutch companies) which were then designated as State enterprises. Then, Law No. 1 of 1969 divided the State Enterprises into three types: State Agencies (Perjan), Public Service Companies (Perum) and State Limited Liability Companies (Persero). This division was formed according to the task, function and mission of the businesses at that time.

Thus, the first task of the state in establishing business entities is to meet all the needs of the people when those sectors cannot be performed by the private companies. Then such tasks are translated into a form of "pioneering" businesses by the State which turns SOEs into agents of development.

As corporate organizations, the aspect of workers can not be separated from the management of SOEs. Workers act as the front guards of a company in realizing its ideals. Manpower is a factor supporting the economy of a country. To promote the economy of a country, a quality relationship between employers and workers is required and becoming mandatory.

Law Number 13 of 2003 on Manpower provides norms in the form of opportunities and convenience for companies to perform efficiency, both in management and finance. The companies may delegate some of the internal work to other companies through a service contract and worker supply agreement. The implementation is regulated in the Minister of Manpower and Transmigration Regulation No. 27 of 2014 on Amendment to the Regulation of the Minister of Manpower and Transmigration No. 19 of 2012 on Terms of Submission of Some of the Internal Work to Other Companies (Permenakertrans). This condition then triggered the issues of outsourcing problem in Indonesia.

\section{Research method}

This research employs a normative[6] legal [7] approach by analyzing legal materials[8] and conducting literature studies[9] to be used as secondary data covering official 
documents, library books, rules and regulations, scientific papers, articles, and documents related to the research. All subsequent data are then analyzed using theories to answers the problems in this research.

\section{Literature review}

The idea of a welfare state has been introduced since around the 18th century. According to Bessant, Watts, Dalton and Smith, the basic idea of the welfare state dated back to the 18th century when Jeremy Bentham (1748-1832) promoted the notion that government has a responsibility to guarantee the greatest happiness (or welfare) of the greatest number of their citizens. Bentham used the term 'utility' to explain the concept of happiness or welfare. Based on the principle of utilitarianism that he developed, Bentham argued that something that can lead to extra happiness is good. Conversely, something that causes pain is bad. In his opinion, the actions of the government should always be directed to increase happiness toward as many people as possible. Bentham's notions of legal reform, role of constitution and social research for the development of social policieshas made him known as the "father of welfare states." [10]

The keyword in the welfare state is the issue of people's welfare guaranteed by the state. Jurgen Habermas argued that the welfare of all people is essential to the modern state. Furthermore, according to Habermas, the welfare of all the people is manifested in the following protection: the risk of unemployment, accident, illness, old age and death of the breadwinner must be covered largely through welfare provisions of the state.[11]

The basic concept of a welfare state can be seen from the state's efforts to manage all existing resources in order to achieve one of the state's goals, that is to improve the welfare of its people. These ideals are then translated in a policy that has previously been consulted to the public. As such, it can be seen whether or not a country has really realized the welfare of its citizens. The poverty and public health are some of the problems that the government must respond to in the formulation of a welfare policy.

The economic development undertaken by a welfare state must correlate with the welfare and prosperity of the people. This principle is the main task that must be realized in the welfare state. According to Habermas, there are two things that are directly related to economic development efforts: First, the realization of a welfare state cannot be separated from economic development efforts. As stated earlier, an economic development should make people more prosperous not the other way around. Second, the goal of the realization of a welfare state is not only for equality, but also for efficiency in the economic process. Ideally, the reason for equality or equity should not conflict with the purpose of efficiency in the economy. These two things become part of the welfare goals. In designing a welfare state, there are two important questions that must be addressed: Firstly, what is the purpose of a policy?, and secondly, by what method can the goal be achieved? These two questions can at least explain whether or not a country's policy seeks to realize the welfare of the people.[12]

The essence of a welfare state can be described as being the influence of human desires which expect to assure security, peace and prosperity in order not to fall into misery. The reason can be described as a driving force as well as a goal for humans to constantly seek various ways to achieve prosperity in life. So, when the wishes have been guaranteed in the constitution of a country, then they must be guaranteed by the state and the state must realize the wishes. In this context, the state exists in the stages of being a welfare state.

The Unitary State of the Republic of Indonesia also embraces the welfare state ideology. This was confirmed by the Pioneers of Independence and the Founders of the Unitary State of the Republic of Indonesia who declared that the democratic state to be established was the "Welfare State" (walvaarstaat) not the "the State of the Night-Watch" 
(nachtwachterstaat). In determining the concept of a welfare state for Indonesia, Moh. Hatta used the term "Governing State."[13] In a similar view, Jimly Asshiddiqie said that "... Indonesia is a welfare state that idealizes the nature of state interventionism in the dynamics of the social economy, solely for the welfare of the people".[14]

\section{Result and discussion}

Workers or employees play an important position in the production process of a company. Every company needs to make an employment plan according to the needs of the company which should match to the needs of the employees. This has become the goal of formulating the Law on Manpower.

With regard to the employment regulation between employers and workers, the Law on Manpower ranks at the top position. Under this Law, the employment relationship occurs due to an employment agreement between employers and workers. Article 1313 of the Civil Code states that an agreement is an act by which one or more persons commit themselves to one or more persons. The definition of agreement, as written down in Article 1313 of the Civil Code, only mentions the clause one party or more binding itself to the other but does not clearly specify for what purpose an agreement is made. Wiwoho argued that an agreement can also be interpreted as the relationship between a person who acts as a worker/laborer with someone who acts as an employer.[15]

The definition of the employment agreement is firstly mentioned in the provisions of Article 1601a of the Civil Code which reads: An Employment Agreement is an agreement whereby one party (the worker) binds himself to be under the command of the other party (the employer), for a certain period of time, performs work and receives wages. The phrase "under the command of the other" means that there is a relationship between workers and their employer, the relationship between subordinates and their superior where employers give orders to workers to do a certain work. There is a governing authority in an employment agreement which distinguishes it from other agreements.According to $\mathrm{R}$. Imam Soepomo, the employment agreement is an agreement in which the first party, the laborer, binds himself to work by receiving wages from the other party, the employer, who binds himself to hire the laborer by paying the wages.[16]

The nature of a worker-employer relationship is basically contradictory, where on the one hand it seeks colaborative relations, but on the other hand there are potential trends which can lead to adversarial relations. When signing an individual contract, the worker and the employer are legally equal before the law in accordance with the principle of equality before the law, but sociologically the employer occupies a higher socio-economic position compared to the worker. Even in the context of a company, there are some opinions assuming that labor is only an external factor. The worker has a similar position as the supplier or buyer who serves as a supporter of the company's continuity, not as an internal part of the company which is inseparable or as a constructive element that builds the company.[17]

In the management of SOEs, outsourced labor is an issue that needs attention. This statement is based on research and surveys conducted by management experts over the last twelve years in more than 1,200 companies. They expect to gain significant business benefits from outsourcing recruitment practice.[18]

Outsourcing employment in Indonesia is conducted only for supporting work or activities or commonly called non-core business activities. It is not for the main work or activities or commonly referred to as the core business. Article 64 of the Law on Manpower states that a company may subcontract some of its work to another company under a written contract for the provision of service/labor. 
However, employers make use of this system not for the efficiency of work management or to seek out the experts in their field. They make use of this employment system solely for cost-cutting reason. In fact, violation to the Law is still going on. Referring to the Regulation (Permenakertrans), there are only five types of work that can be outsourced and they exclude the main activities. However, a number of state-owned companies noticeably outsourced sometypes of work outside the provisions.[19]

Another problem is the uncertainty experienced by the outsourced workers because of an unclear working relationship. There is no legal relationship between outsourced workers and their employing company (user). There are no rights and obligations that are directly related between the two, for example, orders come from outsourcing companies to outsourced workers.

Based on Article 56 of the Manpower Law, there are 2 (two) types of employment agreements, namely the Certain Time Working Agreement (PKWT) and Non-Specific Time Working Agreement $(P K W T T)$. PKWT is an employment agreement between the worker/laborer and the employer to establish a working relationship within a certain period of time or for a particular job or for a certain temporary job. PKWTT is an employment agreement between the worker/laborer and the employer to establish a permanent employment relationship.[20] PKWTT can be made literally or orally without requiring an approval from the relevant government employment agencies. If the PKWTT is made verbally, then the clauses apply between them (between employers and workers) are clauses as set out in the Manpower Law.

The PKWT is a conditional agreement that is (among other things) required to be written and made in the Indonesian language, under the sanction that if it is not made in writing or not made in the Indonesian language, it is deemed as PKWTT (Article 57 Paragraph (2) of Manpower Law). PKWTT may require a maximum period of 3 (three) month probation. During the probation period, the employer is required to pay the wage which must not be lower than the prevailing minimum wage.

Work relationships are created when there is an agreement between employers and workers through a contract. This requirement also applies when subcontracting companies work for other parties. The types of work that can be subcontracted must meet the following requirements: a) done separately from the main activities; b) carried out by direct or indirect orders from the employer; c. serves a supporting activity of the company as a whole; and d) does not inhibit the production process directly.[21]

The types of work which are not directly related to the production process include: [22] a) cleaning service; b) food providing for workers/laborers (catering); c) security service; d) supporting services in mining and petroleum; and e) providing transportation for workers/laborers.

In practice, the applied outsourcing system does not accord with the laws and regulations. Outsourcing tends to be applied in jobs which are directly related to the production process. In addition, there are also neglected workers' normative rights. Laborers who work for jobs directly related to the production process should get the same rights as obtained by the permanent employees.

Based on the Law on Manpower and the Regulation of the Minister of Manpower, the rights of permanent and outsourced employees can comparatively be described as follows:[23]

Tabel 1. Comparison of rights between permanent employees and outsourced employees

\begin{tabular}{|c|c|c|}
\hline Worker's rights & Permanent employee & Outsourced employee \\
\hline Basic Wage & $\begin{array}{l}\text { - Minimum Wage } \\
\text { - Scheduled working hours }\end{array}$ & $\begin{array}{ll}\text { - } & \text { Minimum Wage } \\
\text { - } & \text { Scheduled working hours }\end{array}$ \\
\hline Premium Presence & Yes & No \\
\hline Work $\quad$ Insurance, & Yes & Yes \\
\hline
\end{tabular}




\begin{tabular}{|l|c|c|}
\hline Insurance, and Death Insurance & & No \\
\hline $\begin{array}{l}\text { Payment for food and } \\
\text { transportation }\end{array}$ & Yes & Yes \\
\hline Right to Rest & Yes & Yes \\
\hline Holiday Time & Yes & Yes \\
\hline Work Termination & Yes & Yes \\
\hline Worker's Social Security & Yes & \\
\hline
\end{tabular}

Indonesian laws and regulations do not restrict the ability of an outsourced employee to transition to permanent status. A restriction may, however, be imposed by the laboroutsourcing contract between the employercontractor and the labor provider; such a restriction is permitted by the freedom of contract principle in Article 1338 of the Indonesian Civil Code. Absent such a contractual restriction, an employee of the labor provider may concurrently work as a permanent employee of the primary employer.

Based on the Report of the Working Committee of Commission IX of the House of Representatives regarding Outsourcing Recruitment, it is stated that there are few violations of legal norms by companies include the absence of status change guarantee for contract workers to become permanent workers (PKWTT) pursuant to Article 59 Paragraph (2) of Law No.13 of 2003; workers' wage is paid lower than the regulated minimum wage; the absence of health/safety insurances; unclear relationship between the duration of employment and the status and welfare of the workers; the normative rights they deserve being ignored by the company in terms of THR (Special Holiday Allowance) payment; wage adjustment that must be taken into account from the accumulation of work tenure; social security or other rights regulated in the legislation (Article 29 of Permenakertrans $R I$ No.19 of 2012). Workers' wage is paid lower than the minimum wage (Article 90 Paragraph (1) of Law No.13 of 2003).[24]

The working rules carried out by state-owned enterprises through their directors often violate the provisions of Article 59 of the Manpower Law whereby working agreements for a certain period of time may only be made for certain jobs whosetype, nature or activity will be completed within a specified time.In reality, the jobs performed by the worker through the contracting agreement or the provision of a worker's services were continuous and carried out for the same jobs, neither temporary nor seasonal, or related to new products, new activities or additional products which werestill in a trial process.[25]

\section{Conclusion}

The government as the administrator of the state must be able to create legislation in favor of the people. [26] Any government policy in the form of laws and regulations should be able to create opportunities for the welfare of the people. Thus, the task of the state is to ensure that every regulation should be able to realize the goals of a social welfare. This way, people can clearly feel that the existence of law is instrumental in creating their welfare. This should also become a basic milestone for a law-based country to realize the concept of welfare state in its governance.

The state-based status has turned SOEs into companies managed under the regulation of Limited Liability Companies, but within certain limits, its management is still regulated in the regulation of SOEs which gave birth to SOEs. However, labor-related arrangements and their relation to policy making within the company have not been explicitly regulated in both laws.

When applying the outsourcing system under the Manpower Law, violations are frequently found. The main types of violations that SOEs often commit activities including the continuous use of the outsourcing system which is inconsistent with the legislation and ignores the workers' normative rights. The violationsof the outsourcing system against the 
Manpower Law can be categorized into 3 (three) kinds. First, outsourcing is used for core business activities. Second, people have worked for a relatively long period, an average of over 3 (three) years. In fact, some workers have already workedfor more than 9 (nine) years. And third, the employment contract is repeated for similar type of job and workplace.[27]

Another violation is the absence of protecting the workers' normative rights by the vendors (outsourcing companies). Violation to BUMN labour normative rights covering: severance pay right (reported at PT DI, OS worker at PT PLN Bali, PT Jamsostek, PT Pertamina, others), termination process pay right, occupational allowance right (reported at PT ASKES and ASDP), pension fund benefit right (reported at Perum Peruri, Perum Damri, PTPN II Sumut-Langkat), overtime and annual leave pay right (reported at PLN, PT Petrokimia), payment under minimum wage (reported at PT Kimia Farma, PT Petrokimia, Perum Damri Kantor Surabaya, others), occupational health and safety right, and social security right (reported at PT PLN, PT Petrokimia Gresik), and other rights.[27]

The Law on Limited Liability Company, as a reference for SOEs in its management, has not placed workers as a strategic partner in the management of the state businesses although the SOEs Law has provided a space for the management of SOEs to refer to the Manpower Law for matters relating to employees as state-owned enterprise workers.

SOEs as a legal company are not only seen to have an organ as stipulated in the Law on Limited Liability Company. In carrying out their activities, workers have a leading role in implementing the company policies. In the development history of Limited Liabilty SOEs in Indonesia, manpowerhas received less attention. As such, it is necessary to change the paradigm that has set workers as controlled variables (factors of production) to be one of the stakeholders or strategic partners in the management of Limited Liability SOEs.

A quality relationship will create a conducive situation and synergy which will eventually improve the company's performance. Comfortable and secure working atmosphere are the benchmark in creating conducive company. Thus, it will not be difficult for a company to achieve its goal, if the relationship between workers and their employer runs harmoniously. If the harmonious relationship continues to work, the goals mandated by the Constitution to create a welfare state in Indonesia will not be difficult to achieve.

\section{References}

1. Welfare State, Encyclopedia Britannica, http://www.britannica.com/print/topic/ 639266, retrieved on 27 April 2018.

2. P. Christopher, Welfare state: The new political economy of welfare, p. 9 (Pennsylvania State University Press, Pennsylvania, 2007).

3. A. Briggs, Welf.St. His.Pers, E.J.S, Vol. 2 (2), pp. 221-258, (1961).

4. K.S. Aziza, I Semester of 2017 of BUMN Revenue at 936 trillion IDR, https://ekonomi.kompas.com/read/2017/08/29/202938326/semester-i-2017pendapatan-bumn-rp-936-triliun., retrieved on 27 April 2018

5. B. Rothstein, Just institution matter: The moral and political logic of the universal welfare state. p.8 (Cambridge University Press, Cambridge UKs, 1998)

6. J. Ibrahim, Teori dan metodologi penelitian hokum normatif, p. 295 (Bayumedia Publishing, Malang, 2006).

7. R.H. Soemitro, Metodologi penelitian hukum dan jurimetri, pp. 13-14 (Ghalia Indonesia, Jakarta, 1988).

8. S. Soekanto, and S.Mamudji, Penelitian hukum normatif, suatu tinjauan singkat, p.12 (Raja Grafindo Persada, Jakarta, 2011).

9. Ibid, p. 13 
10. J. Bessant, R.Watts, T.Dalton, and P.Smith,Talking policy: How social policy in made, crows nest: allen and unwin, (2006 in E. Suharto, Peta dan dinamika welfare state di beberapa negara: pelajaran apa yang bisa dipetik untuk membangun indonesia?, paper presented at a Seminar entitled "Mengkaji ulang relevansi welfare state dan terobosan melalui desentralisasiotonomi di indonesia", (IREYogyakarta and Perkumpulan Prakarsa,Jakarta, Yogyakarta 25 July 2006)

11. G. Poggi, The development of the modern state "sosiological introduction", p.126 (Standford University Press, California, 1992).

12. B. Nicholas.The economics of the welfare state. (Stanford University Press, California, 1998).

13. M. Yamin, Naskah persiapan UUD 1945: Risalah sidang BPUPKI/PPKI, p.299, (Sek.Neg.RI, Jakarta, 1959); compare with M.Kusuma, Lahirnya UUD 1945, p.355 (Badan Penerbit FH UI, Jakarta, 2004)

14. J. Asshiddiqie, Gagasan konstitusi sosial: Institusionalisasi dan konstistusionalisasi kehidupan sosial masyarakat madani, p.122 (Pustaka LP3ES, Jakarta, 2015).

15. W. Soedjono, Hukum perjanjian kerja, p.9 (Rineka Cipta, Jakarta, 1991).

16. I. Soepomo, Hukum perburuhan bagian pertama hubungan-kerja, p.75 (Bhayangkara, Jakarta, 1968).

17. H.P. Rajagukguk, Peran serta pekerja dalam pengelolaan perusahaan (codetermination), A talk on a discussion panel: "75 Tahun Dr. H.P. Rajagukguk, S.H”p.3 (Fakultas Hukum UKI, Program Kajian Wanita dan Gender Pascasarjana UI, dan Fakultas Hukum UI, Jakarta, 2000)

18. R.E. Indrajit, R. Djokopranoto, Proses bisnis outsourcing, pp.4-5 (2003).

19. N.C. Burkholder, Outsourcing (the defitive view, applications, and implications). p.6 (J. Wiley and Sons, Inc, Hoboken, New Jersey, 2006)

20. Article 1 point $2 \mathrm{~A}$ Decree of Man Power and Transmigration Minister of RI No.KEP. 100/MEN/VI/2004 on the Implementation of Temporary Appointment Work Agreement (Kepmenakertrans 100/2004)

21. Article 65 Paragraph 2 of Manpower Law

22. Article 17 Paragraph (3) Regulation of the Minister of Man Power.

23. R. Bales, S.B. Audyanto, S. Guven, M. Jockel, C.B. Juniarto, J. Junlu, \& D. Langmead, A Comp. An. of Lab. Outsourc, AJICL Vol. 31, No. 3, pp.580-622 (2014)

24. Laporan Panitia Kerja Outsourcing BUMN Komisi IX DPR RI Masa Sidang 20132014, DPR RI, (2013).

25. Meeting Report between BUMN Labour and Komisi IX DPR RI (House of the Representative)attended by Ministry of Labour, Ministry of Finance, Ministry of BUMN, Representatives of the Boards of Directors of PLN, Pertamina, PGN, Krakatau Steel, Indofarma, JasaMarga, and Garuda Indonesia, on 7 February 2018, (https://www.bantuanhukum.or.id/web/geber-bumn-menanti-dpr-tuntaskan-kasusoutsourcing-di-bumn/retrieved on, 1 May 2018).

26. Y. Suhardin, Perananhukumdalammewujudkankesejahteraanmasyarakat, JHPJ, Vol. 25 No. 3, p.273 (July 2007)

27. K.S. Cahyono, Perbudakan modern di BUMN, p.4 (PT Leutika Nouvalitera, Yogyakarta, 2015) 